
3 Research Square
Preprints are preliminary reports that have not undergone peer review.
They should not be considered conclusive, used to inform clinical practice, or referenced by the media as validated information.

\title{
Safety and Efficacy of Therapeutic Taping in Primary Dysmenorrhea: a Systematic Review and Meta-analysis
}

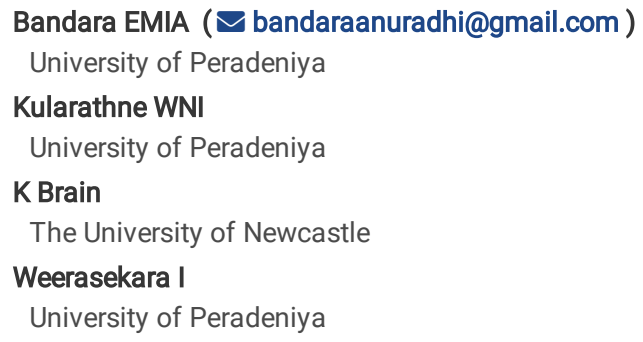

\section{Research Article}

Keywords: Primary dysmenorrhea (PD), ETT, adult women, therapeutic taping

Posted Date: September 16th, 2021

DOI: https://doi.org/10.21203/rs.3.rs-827953/v1

License: () (1) This work is licensed under a Creative Commons Attribution 4.0 International License. Read Full License 


\section{Abstract}

Primary dysmenorrhea (PD) is a common gynecological complaint among adolescents and adult women. Various pharmacological and alternative therapies such as therapeutic taping have been used as a treatment of PD. Although several studies have been conducted to evaluate the safety and efficacy of therapeutic taping in PD, these studies have not provided adequate level of evidence related to the safety and efficacy of therapeutic taping in PD. Hence, a systematic review and meta-analysis was performed to evaluate the safety and efficacy of therapeutic taping in PD. The following databases; Medline, Cochrane Library, Embase, PEDro, CINAHL and any other gray literature sources were searched for randomized controlled trials (RCTs) that used therapeutic taping to treat PD from inception to June 2021 with the language restricted to English. Independently screened articles by two reviewers were extracted according to the study objectives. A total of nine studies were included in the systematic review, involving 577 participants. Three studies were eligible for meta-analysis to find the pooled effect of taping on pain intensity. The review indicates that therapeutic taping is an effective measure in improving pain, anxiety and quality of life of women with PD. Meta-analysis conducted to compare the effect of elastic therapeutic taping (ETT) to sham taping showed that the ETT is an effective measure in improving pain among women with PD (MD = $\left.-3.12(95 \% \mathrm{Cl}-5.64,-0.60) ; p=0.02 ;\left.\right|^{2}=95 \%\right)$. The quality of the studies was assessed using the PEDro scale and the included RCTs indicated a fair to good level of quality. Our systematic review and meta-analysis demonstrated that therapeutic taping is an effective intervention for PD. However, RCTs with higher quality and larger sample sizes are necessary to verify the current results of the review.

\section{Introduction}

Dysmenorrhea is a painful, cramping sensation that occurs in the lower abdominal area accompanied by other biological features such as, backpain, nausea, vomiting, sweating, dizziness, headache, diarrhea and tiredness ${ }^{1}$. These symptoms usually occur a few days before or during menstruation ${ }^{1,2}$. The burden of dysmenorrhea is significantly higher than any other gynecological complaint ${ }^{3}$. It is a prominent cause of gynecological morbidity in females of reproductive age 4,5 . Prevalence is high, with 45-93\% of women in their reproductive age experiencing dysmenorrhea, and the highest rates are reported in adolescent girls 3,6 . Depending on the pathophysiology, dysmenorrhea can be divided into two categories; primary and secondary ${ }^{7}$. Primary dysmenorrhea (PD) is described as a cramping pain in the lower abdomen which occurs without any obvious pelvic pathology ${ }^{1}$. Secondary dysmenorrhea is described as the menstrual pain caused by underlying pelvic pathology such as endometriosis, adenomyosis, intra uterine adhesions, cervical stenosis, ovarian cysts, uterine myomas or polyps, infertility problems and pelvic inflammatory disease and the onset may be years after first menstruation ${ }^{8,9}$. PD first occurs after menarche, in women who are under 20 years of age ${ }^{1}$. The exact cause of PD is not well identified. However, it is hypothesized that excessive production of uterine prostaglandins, particularly of PGF2a and PGF2 is involved in the pathogenesis of PD ${ }^{10}$. Excessive uterine prostaglandin levels lead to increased uterine tone and high amplitude contractions ${ }^{10}$. Several risk factors for PD have been identified, such as age (<20 years), smoking, nulliparity, longer and heavy menstrual flow, high body mass index (BMI), earlier onset of menarche, family history, depression, anxiety and stress ${ }^{11,12}$. Women experiencing PD often have poor physical, mental and social wellbeing due to the negative impact dysmenorrhea can have on everyday life. Poor academic performance, absenteeism from school and work, limitations on daily activities, poor quality of sleep, increased levels of stress, anxiety and depression are examples of the reported consequences of PD $1,4,8$. Consequences not only affect women on an individual level, but they also have an impact on the community and economy with decreased productivity leading to economic loss ${ }^{1,4}$. However, most women do not report or seek medical attention for PD, because it is considered a normal feature of menstruation 13

Both pharmacological and nonpharmacological treatments are available to manage PD ${ }^{14}$, while surgical procedures are also available for extreme cases ${ }^{15}$. Pharmacological treatments target the physiological mechanisms associated with menstrual pain and other symptoms. Aspirin, paracetamol and nonsteroidal anti-inflammatory drugs (NSAIDs) are believed to reduce the activity of cyclo-oxgenase pathways, thus inhibiting excessive production of prostaglandins. Oral contraceptives are also used to inhibit ovulation. A combination of analgesics and oral contraceptives may be useful in cases where women don't respond to a single treatment ${ }^{7}$. There are some side-effects associated with analgesics and contraceptives such as gastrointestinal disturbances (nausea, vomiting and diarrhea) with the use of NSAIDS while nausea, abdominal pain, headache, acne, bloating, anxiety, loneliness and weight gain were observed with the use of oral contraceptives ${ }^{7,16}$. Approximately, $10-20 \%$ of women do not respond to pharmacological management and some may have contraindications for the use of NSAIDs and oral contraceptives ${ }^{7}$. Evidence shows that the use of alternative treatments can be effective in relieving pain and symptoms. Some examples include herbs such as aloe vera, chamomile, cinnamon, fennel, and ginger ${ }^{17}$, dietary changes such as a low-fat vegetarian diet, vitamins ( $B, C, E$ ), and supplements (calcium and magnesium) ${ }^{18,19,20}$, hypnosis and psychotherapy ${ }^{19}, 20$. Physiotherapy treatments also play a role in managing PD. Generally, physiotherapy treatments for PD include heat therapies, exercises, relaxation therapies, connective tissue massage, acupressure, acupuncture, Transcutaneous Electrical Nerve Stimulation (TENS), spinal manipulation and taping such as kinesio-taping (KT) and elastro-tapes 20,21

There are a variety of tapes available, each with different types, materials and uses. Common tapes are; rigid tapes (a non-elastic and non-permeable), kinesio tapes, elastic tape, and spiral tapes (a non-elastic synthetic tape applied in a spiral or grid shape) ${ }^{22}$. Spiral tapes may generate cutaneous stimuli, reduce pain and swelling, improve circulation and regulate muscle tone and metabolism ${ }^{23}$. Kinesio taping (KT) is a specially designed elastic tape designed to maintain air permeability, be water-resistant and contain hypoallergic materials. This taping type is clinically used widely as it has a strong adherence capacity, low risk of skin irritation, easy and self-applicability, and long-lasting capacity. KT is found to be effective in reducing pain, supplying proprioceptive feedback, stimulating muscle activity, supporting weak muscles, and increasing lymphatic and blood flow to the applied area 24,25 .

There are several research studies that have investigated the effectiveness of taping on PD, however there is no systematic review or a meta-analysis. This current systematic review and meta-analysis aims to determine whether taping is an effective and safe treatment for PD in improving pain and related clinical symptoms such as anxiety. 


\section{Method}

The study protocol for this systematic review was registered with International prospective register of systematic reviews (PROPERO) on 24th June 2021 (CRD42021256578).

\section{Eligibility criteria}

Randomized controlled trials (RCT) published in English were included if they assessed women, of any age, with PD. Study participants had to be treated with therapeutic tape applications aimed to treat pain associated with PD (alone or as a combination with another therapy) e.g.: elastic therapeutic tape (ETT), rigid therapeutic tape (RTT) and spiral tape. Studies with other therapeutic intervention, sham taping or no intervention control groups were included. Studies also had to include a measure of pain to be considered eligible for inclusion. Studies which satisfied the following criteria were excluded; study protocols, abstractonly papers (eg: proceeding papers, conference abstracts, editorials, and commentaries), and where full text were not available.

\section{Search strategy}

We searched the following electronic databases; CINAHL, Cochrane Library, EMBASE, MEDLINE and PEDro; with keywords related to therapeutic taping and PD. All searches were conducted from inception to May 2021. The MEDLINE search strategy is provided in Appendix 1. Additionally, Google Scholar was searched using the same keywords to identify other potential studies.

\section{Study selection process and screening}

All references were exported to Endnote and then transferred to Covidence for de-duplication, screening and data extraction. Two reviewers independently screened the title and abstract against a pre-defined eligibility criterion. The full texts of relevant abstracts were then screened by the same reviewers using the same process. Disagreements were resolved by consensus. The number of included and excluded articles at the different phases was recorded as recommended by PRISMA guidelines and presented in a flowchart (Fig. 1).

\section{Data extraction}

The following data were independently extracted from the included studies by two reviewers. Any disagreements were resolved through discussion or by consultation a third reviewer. Publication details including research title, author details, year of publication, country of investigation; details of the sample including sample size and age of each control/intervention group; details of the intervention and comparison groups including type and taping technique, frequency and treatment duration, outcome indicators and the significance of findings (eg: pain score, pain duration, anxiety and menstrual discomfort measures) and, adverse events. When the information was missing, or unclear relevant authors were contacted to obtain the necessary information.

\section{Data analysis}

Collated evidence was summarized and presented narratively using tables and graphs. Where possible, similar studies were pooled together for meta-analysis.

The meta-analysis was conducted using random effect model if statistical heterogeneity, $I^{2}>50$, and the mean difference (MD) was used if the studies used the same tool to measure the interested outcomes. Each effect was expressed at $95 \%$ of confidence interval and statistical significance at $p<0.05$. The statistical analysis was carried out in RevMan5.4 software.

\section{Quality assessment}

Quality of the included studies was assessed using the PEDro scale ${ }^{26}$. Two reviewers independently assessed the quality of the included RCTs and any discrepancies were resolved by consensus. The PEDro scale consists of 11 scored items. The first item relates to the eligibility criteria and is not included in the final PEDro score. The scores from the remaining 10 items are added together to generate an overall PEDro score which is used to determine the quality of the study. Eight of these items are related to the methodological quality of the study (e.g. allocation, baseline comparability, blinding, adequate follow up and intention-to-treat). The final two items are related to statistical reporting (between group comparison, point estimates and variability) ${ }^{26}$.

\section{Grading of evidence}

Grading of evidence was done based on the PEDro score. The evidence was categorized into three levels of strength; strong, moderate and low ${ }^{27}$ where a strong level evidence was defined as the evidence stemming from preponderance of high quality RCTs (PEDro 7-10). Moderate level evidence was defined as the evidence stemming from findings if one high quality RCT, inconsistent findings from preponderance of high quality RCTs, or consistent findings from preponderance moderate quality RCTs (PEDro 4-6) while low level evidence was defined as the evidence stemming from findings if one moderate quality RCT, inconsistent findings from preponderance of moderate quality RCTs, or consistent findings preponderance of low quality RCTs (PEDro 0-3).

\section{Data availability}

The datasets generated during and/or analyzed during the current study are available from the corresponding author on reasonable requests.

\section{Results}

\section{Study selection}

Two hundred and ninety studies were found during the search (number of records through database search, $n=288 ; n=2$ through other sources). There were 41 duplicate records removed leaving 249 studies which were screened at the title and abstract screening phase. After excluding 224 records, 25 full texts were 
screened leaving nine studies for final inclusion in the systematic review. Data from three studies were pooled together for a meta-analysis. The study selection process is presented in Figure 1.

\section{Characteristics of the included studies}

The included nine RCTs enrolled a total of 577 subjects. A total of 250 subjects were enrolled in the experimental group and received therapeutic taping. Control groups included other therapies $(n=146)$, sham taping $(n=93)$ or no intervention $(n=88)$ (Table 1$)$.

\section{Quality evaluation}

Methodological quality was assessed using PEDro scale (Table 2). The PEDro score of the included studies ranged from 4 to 7 . All the studies satisfied the baseline comparability and between group comparison criteria. However, no study met the criteria for subject blinding and therapist blinding (Figure 2).

\section{Evidence summary}

Favorable evidence was found for the effect of Kinesio taping on quality of life outcomes with the evidence being of high quality (Table 3 ). Favorable evidence was found on the effect of Kinesio taping on pain intensity and anxiety with the evidence being of moderate quality (Table 3 ). Favorable evidence was found on the effect of spiral taping and balance taping on pain intensity (Table 3). 


\begin{tabular}{|c|c|c|c|c|c|c|c|c|c|}
\hline \multirow[t]{2}{*}{ Study } & \multirow[t]{2}{*}{ Country } & \multirow{2}{*}{$\begin{array}{l}\text { Population } \\
\text { (sample, age, } \\
\text { setting) }\end{array}$} & \multirow{2}{*}{$\begin{array}{l}\text { Sample } \\
\text { size }\end{array}$} & \multicolumn{2}{|l|}{ Intervention } & \multicolumn{2}{|c|}{ Duration of treatment } & \multirow{2}{*}{$\begin{array}{l}\text { Outcome Indicators } \\
\text { (tool) }\end{array}$} & \multirow[t]{2}{*}{ Res } \\
\hline & & & & $\begin{array}{l}\text { Experimental } \\
\text { (sample size) }\end{array}$ & $\begin{array}{l}\text { Comparison } \\
\text { (sample } \\
\text { size) }\end{array}$ & Experimental & Comparison & & \\
\hline Pazare 2019 & India & $\begin{array}{l}\text { Females with } \\
\text { PD } \\
\text { 18-25 years } \\
\text { PCMC area, } \\
\text { Pune }\end{array}$ & 40 & KT (20) & $\begin{array}{l}\text { Isometric } \\
\text { Exercises } \\
(20)\end{array}$ & $\begin{array}{l}3 \text { weeks } \\
\text { (six times twice } \\
\text { a week starting } \\
\text { from } 14 \text { days } \\
\text { before } \\
\text { menstruation } \\
\text { until its end) }\end{array}$ & $\begin{array}{l}8 \text { weeks } \\
\text { (since the } \\
\text { third day of } \\
\text { their } \\
\text { menstrual } \\
\text { cycle } \\
5 \text { days a } \\
\text { week, two } \\
\text { sessions a } \\
\text { day, and } 10 \\
\text { times per } \\
\text { Session) }\end{array}$ & Pain intensity (VAS) & $\begin{array}{l}\text { KT } \\
\text { sigr } \\
\text { imf } \\
\text { pail } \\
\text { con } \\
\text { isol } \\
\text { exe }\end{array}$ \\
\hline Dogan 2020 & Turkey & $\begin{array}{l}\text { Nulliparous } \\
\text { females } \\
\text { diagnosed } \\
\text { with PD } \\
\text { Over } 18 \text { years } \\
\text { NR }\end{array}$ & 60 & $\begin{array}{l}\text { KT + Lifestyle } \\
\text { changes (30) }\end{array}$ & $\begin{array}{l}\text { Lifestyle } \\
\text { changes } \\
(30)\end{array}$ & $\begin{array}{l}1 \text { month (first } \\
\text { day of the } \\
\text { second } \\
\text { menstrual } \\
\text { cycle to the } \\
\text { first day of the } \\
\text { third menstrual } \\
\text { cycle) }\end{array}$ & $\begin{array}{l}1 \text { month (first } \\
\text { day of the } \\
\text { second } \\
\text { menstrual } \\
\text { cycle to the } \\
\text { first day of } \\
\text { the third } \\
\text { menstrual } \\
\text { cycle) }\end{array}$ & $\begin{array}{l}\text { Pain intensity (VAS) } \\
\text { Number of } \\
\text { analgesics } \\
\text { The Quality of life } \\
\text { (Turkish version of } \\
\text { the SF-36) scale }\end{array}$ & $\begin{array}{l}\text { KT } \\
\text { witl } \\
\text { cha } \\
\text { sigr } \\
\text { imp } \\
\text { paiı } \\
\text { redı } \\
\text { qua } \\
\text { anc } \\
\text { aw: } \\
\text { con } \\
\text { life: } \\
\text { cha } \\
\text { alo }\end{array}$ \\
\hline Kaur 2017 & India & $\begin{array}{l}\text { Female } \\
\text { students with } \\
\text { complains of } \\
\text { PD, } \\
\text { Between 18- } \\
25 \text { years } \\
\text { MVP's } \\
\text { college of } \\
\text { Physiotherapy, } \\
\text { Nashik; }\end{array}$ & 40 & KT (20) & $\begin{array}{l}\text { Connective } \\
\text { Tissue } \\
\text { Mobilisation } \\
(20)\end{array}$ & $\begin{array}{l}3 \text { days } \\
\text { ((starts one } \\
\text { day before } \\
\text { menstruation) }\end{array}$ & $\begin{array}{l}3 \text { days } \\
\text { (starts one } \\
\text { day before } \\
\text { menstruation. } \\
\text { The } \\
\text { intervention } \\
\text { consisted of } \\
20 \text { minutes } \\
\text { session) }\end{array}$ & Pain intensity (NRS) & $\begin{array}{l}\text { Bot } \\
\text { con } \\
\text { tiss } \\
\text { mo } \\
\text { are } \\
\text { eff } \epsilon \\
\text { imp } \\
\text { pail }\end{array}$ \\
\hline $\begin{array}{l}\text { Boguszewski } \\
2020\end{array}$ & Poland & $\begin{array}{l}\text { Females with } \\
\text { complaints of } \\
\text { pain during } \\
\text { menstruation }\end{array}$ & 44 & $\begin{array}{l}\text { Elastic K- } \\
\text { Active® KT } \\
\text { (16) }\end{array}$ & $\begin{array}{l}\text { Placebo } \\
\text { application } \\
\text { by using an } \\
\text { inelastic } \\
\text { tape (14) }\end{array}$ & 5 days & 5 days & $\begin{array}{l}\text { Pain intensity (VAS) } \\
\text { Pain severity } \\
\text { (modified } \\
\text { version of the } \\
\text { Laitinen } \\
\text { questionnaire) }\end{array}$ & $\begin{array}{l}\text { Bot } \\
\text { plar } \\
\text { app } \\
\text { ma' } \\
\text { mei } \\
\text { pail } \\
\text { Hor } \\
\text { stat } \\
\text { sigr } \\
\text { diff } \\
\text { bet } \\
\text { inte }\end{array}$ \\
\hline $\begin{array}{l}\text { Abdelaziz } \\
2020\end{array}$ & Egypt & $\begin{array}{l}\text { Females } \\
\text { with } \\
\text { complaints of } \\
\text { pain and } \\
\text { cramping } \\
\text { during } \\
\text { menstruation }\end{array}$ & 60 & KT (30) & $\begin{array}{l}\text { Pilate } \\
\text { exercises } \\
(30)\end{array}$ & $\begin{array}{l}\text { Three } \\
\text { consecutive } \\
\text { menstruation - } \\
\text { begins one } \\
\text { day before } \\
\text { menstruation } \\
\text { and would be } \\
\text { remain } \\
\text { adhered for }\end{array}$ & $\begin{array}{l}12 \text { weeks: } 3 \\
\text { days a week, } \\
\text { except the } \\
\text { days of } \\
\text { menstruation }\end{array}$ & $\begin{array}{l}\text { Pain intensity (VAS) } \\
\text { Quality of life } \\
\text { enjoyment and } \\
\text { satisfaction (Q-LES- } \\
\text { Q-SF) }\end{array}$ & $\begin{array}{l}\text { Bot } \\
\text { pila } \\
\text { exe } \\
\text { wer } \\
\text { effe } \\
\text { imf } \\
\text { of } F \\
\text { qua } \\
\text { anc }\end{array}$ \\
\hline
\end{tabular}




\section{to 20 years}

Gynecological

and obstetric

outpatient

clinic of

Eltebeen

central

hospital
Anxiety levels

(Spielberger

questionnaire (State-

Trait Anxiety

Inventory (STAI)

Form Y-1 and Y-2))
Pila

exe

was

red

qua

imp

anc

\begin{tabular}{|c|c|c|c|c|c|c|c|c|c|}
\hline \multirow[t]{2}{*}{$\begin{array}{l}\text { Rodríguez } \\
2015\end{array}$} & \multirow[t]{2}{*}{ Spain } & $\begin{array}{l}\text { Female } \\
\text { students who } \\
\text { suffer from } \\
\text { PD }\end{array}$ & 129 & $\begin{array}{l}\text { A special } \\
\text { elastic and } \\
\text { hypoallergenic } \\
\text { surgical tape } \\
\text { (Cure Tape) } \\
\text { (75) }\end{array}$ & $\begin{array}{l}\text { Non- } \\
\text { extendible } \\
\text { meshed } \\
\text { bandage } \\
\text { patches } \\
\text { (Cross }\end{array}$ & \multirow[t]{2}{*}{$\begin{array}{l}\text { 4-5 days from } \\
\text { menstruation } \\
\text { (Until pain } \\
\text { disappears) }\end{array}$} & \multirow[t]{2}{*}{$\begin{array}{l}\text { 4-5 days from } \\
\text { menstruation } \\
\text { (Until pain } \\
\text { disappears) }\end{array}$} & $\begin{array}{l}\text { Pain intensity }(\text { a } 10- \\
\text { point scale }(0=\text { no } \\
\text { pain and } 10= \\
\text { maximum pain }))\end{array}$ & $\begin{array}{l}\text { Cur } \\
\text { app } \\
\text { sigr } \\
\text { imp } \\
\text { pail } \\
\text { mel }\end{array}$ \\
\hline & & NR & & & Tape) (54) & & & & $\begin{array}{l}\text { con } \\
\text { plaı } \\
\text { app }\end{array}$ \\
\hline
\end{tabular}

School of

Medicine from

the

Universidad

Miguel

Hernández of

Elche

$\begin{array}{lll}\text { Celenay } & \text { Turkey } & \text { Females with } \\ (2020) & & \text { PD, who wer }\end{array}$

nulliparous

KT

(15)

Sham tape

1 month (two

days a week,

from the

estimated day

of ovulation

(cycle length in

Between 18 to

35 years

NR days minus

14) until the next period begins)

Control

group (15)

\begin{tabular}{|c|c|}
\hline $\begin{array}{l}1 \text { month (two } \\
\text { days a week, } \\
\text { from the } \\
\text { estimated } \\
\text { day of } \\
\text { ovulation } \\
\text { (cycle length } \\
\text { in days } \\
\text { minus 14) } \\
\text { until the next } \\
\text { period } \\
\text { begins) }\end{array}$ & $\begin{array}{l}\text { The level of anxiety } \\
\text { (STAI) }\end{array}$ \\
\hline
\end{tabular}

1 month

\begin{tabular}{|c|c|c|c|c|c|c|c|c|}
\hline Yum (2017) & $\begin{array}{l}\text { Republic } \\
\text { of Korea }\end{array}$ & $\begin{array}{l}\text { Between 13- } \\
15 \text { years } \\
\\
\text { Middle school } \\
\text { located in } \\
\text { Seoul }\end{array}$ & 125 & $\begin{array}{l}\text { Balance } \\
\text { taping (33) }\end{array}$ & $\begin{array}{l}\text { Medication - } \\
1 \text { dose of } \\
\text { Tylenol } 500 \\
\text { mg } \\
(46)\end{array}$ & $\begin{array}{l}\text { Pain intensity } \\
\text { was measured } \\
\text { right before the } \\
\text { taping, as well } \\
\text { as } 1 \text { hour, } 4 \\
\text { hours, } 8 \\
\text { hours, and } 24 \\
\text { hours after }\end{array}$ & $\begin{array}{l}\text { The } \\
\text { medication } \\
\text { group took } \\
\text { only } 1 \text { dose } \\
\text { of Tylenol } \\
500 \text { mg, but } \\
\text { midterm and } \\
\text { final exam } \\
\text { periods were } \\
\text { made an } \\
\text { exception }\end{array}$ & Pain intensity (VAS) \\
\hline
\end{tabular}


Control

group (46)

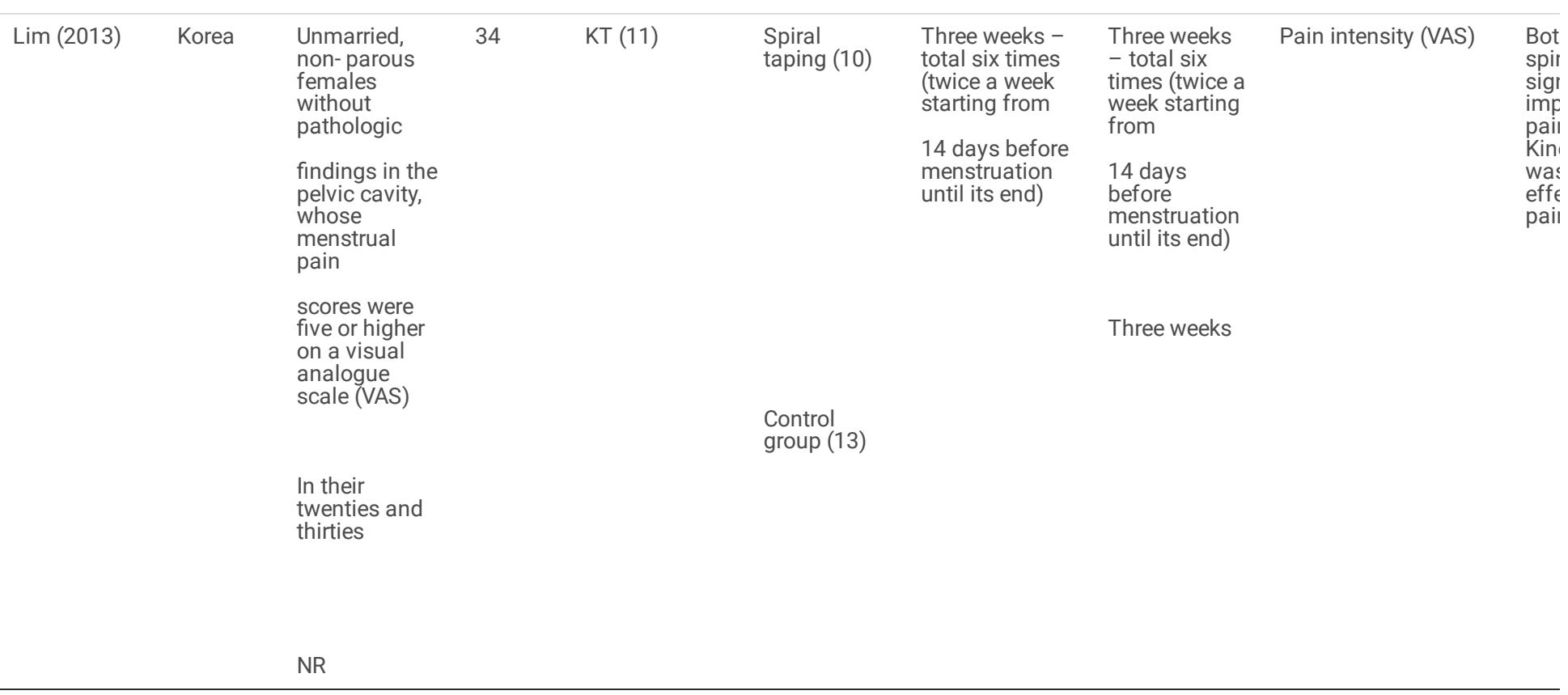

Abbreviations: KT, kinesiotaping; PCMC, Pimpri-Chinchwad Municipal Corporation; PD, primary dysmenorrhea; Q-LES-Q-SF, Quality of life enjoyment and satisfaction; NR, not reported, NRS, numerical rating scale; STAI-X1, (Spielberger statetrait anxiety inventory; ST, sham taping; VAS, visual analogue scale Table 1: Characteristics and summary findings of the included studies

\begin{tabular}{lcccccccccccc}
\multicolumn{1}{c}{ Study } & \multicolumn{1}{c}{ PEDro scale item } & \multicolumn{1}{c}{ PEDro } \\
\cline { 2 - 11 } & 1* & 2 & 3 & 4 & 5 & 6 & 7 & 8 & 9 & 10 & 11 & Score \\
\hline Abdelaziz 2020 & Y & Y & Y & Y & N & N & N & Y & Y & Y & Y & 7 \\
\hline Boguszewski 2020 & N & Y & N & Y & N & N & N & N & N & Y & Y & 4 \\
\hline Celenay 2020 & N & Y & N & Y & N & N & N & Y & N & Y & Y & 5 \\
\hline Dogan 2020 & Y & Y & Y & Y & N & N & Y & Y & N & Y & Y & 7 \\
\hline Kaur 2017 & Y & Y & N & Y & N & N & N & Y & Y & Y & N & 5 \\
\hline Pazare 2019 & Y & Y & N & Y & N & N & N & N & N & Y & Y & 4 \\
\hline Rodríguez 2015 & Y & Y & N & Y & N & N & N & N & Y & Y & Y & 5 \\
\hline Lim 2013 & N & Y & N & Y & N & N & N & Y & N & Y & Y & 5 \\
\hline Yum 2017 & Y & N & N & Y & N & N & N & Y & N & Y & Y & 4
\end{tabular}

Y: yes N:no *: Not considered for total score

1: Eligibility criteria 2: Random allocation 3: Concealed allocation 4: Baseline comparability 5: Blind subjects 6: Blind therapist 7: Blind assessor 8: Adequate follow up 9: Intention to treat analysis 10: Between group comparisons 11: Point estimates and variability

Table 2 Risk of bias evaluation of included studies 


\begin{tabular}{|c|c|c|c|c|}
\hline \multirow[t]{2}{*}{ Outcome indicator } & \multirow[t]{2}{*}{ Type of therapeutic taping } & \multicolumn{3}{|c|}{ Grading of evidence } \\
\hline & & Weak & Moderate & High \\
\hline \multirow[t]{3}{*}{ Pain intensity } & Kinesio taping & & $x$ & \\
\hline & Spiral taping & $\mathrm{X}$ & & \\
\hline & Balance taping & $x$ & & \\
\hline Anxiety & Kinesio taping & & $x$ & \\
\hline Quality of life & Kinesio taping & & & $x$ \\
\hline
\end{tabular}

Table 3: Evidence summary

\section{Effect of therapeutic taping vs no intervention}

Four studies compared the effectiveness of therapeutic taping to a no-intervention control group ${ }^{28-31}$. A total of 173 subjects either received therapeutic taping $(n=85)$ or no intervention $(n=88)$. Three study $(n=143)$ reported an immediate statistically significant pain improvement in therapeutic taping groups compared to no intervention groups ${ }^{29-31}$. The remaining study reported that there was no statistically significant difference in pain improvement among the groups within first 24 hours of treatment ${ }^{28}$. Two studies $(n=60)$ reported a significant improvement of anxiety with KT application compared to no intervention. The overall PEDro scores of the four studies ranged from 4 to 5.

\section{Effect of therapeutic taping vs sham taping}

Three studies ( $n=189)$ compared the effectiveness of therapeutic taping to the sham taping $28,29,32$. All studies reported superior pain relief with therapeutic tape application. However, only two studies $(n=159)$ found a statistically significant difference of pain relief when comparing therapeutic taping and sham taping 29,32 . Two studies $(n=60)$ reported a significant improvement of anxiety with KT application compared to sham taping ${ }^{28,29}$. The overall PEDro scores of the three studies ranged from 4 to 5 .

\section{Effect of therapeutic taping vs other interventions}

Four studies ( $n=219)$ compared the effectiveness of therapeutic taping to other interventions (Pilates, isometric exercises, connective tissue mobilization or medication) ${ }^{30,33-35}$. Two studies $(n=119)$ reported that the therapeutic taping was more effective in pain relief among women with PD compared to other interventions ${ }^{30,33}$. Both studies had a PEDro score of 4 . One study $(n=40)$ reported that the kinesiotaping is similarly effective in relieving pain as connective tissue mobilization ${ }^{34}$. One study $(n=60)$, with a PEDro score of 7 , reported that Pilates exercises provided superior improvements in pain, anxiety and quality of life compared to kinesiotaping ${ }^{35}$.

\section{Effect of therapeutic taping as an adjunct}

One study ( $n=60)$, with a PEDro score of 7, reported that kinesio taping with lifestyle modification is more effective in pain relief, quality of life and body awareness compared to lifestyle modification alone [36].

\section{Meta-analysis of studies assessing the effect of taping on pain intensity of people with PD}

Three studies $29,31,32$ provided adequate data for a meta-analysis, therefore pooled together to quantitively assess the effect of taping on pain intensity in women with PD as assessed by a visual analogue scale (VAS) scale. Given that $\mathrm{I}^{2}$ was $95 \%$, a random effect model was used, and mean difference (MD) was chosen because all studies used a VAS to assess the pain intensity. They had investigated different types of taping as comparison (sham tape (multi-colored sports taping), non-extended tape and spiral taping). With pooled studies, 101 females with PD who were treated using taping (K-taping; $\mathrm{n}=2$ and surgical taping; $n=1$ ) were compared with 82 who were treated with sham tape, non-extended tape or spiral taping. The pooled mean of those found to have decreased menstrual pain intensity among PD (pooled MD=-3.12 (95\% $\left.\mathrm{Cl}^{-5} 5.64-{ }^{-0} 0.60\right) ; \mathrm{P}=0.02 ; \mathrm{I}^{2}=95 \%$ (Figure 3).

\section{Adverse events}

Three studies investigated potential adverse effects of taping 29,30,36. Two studies $(n=60)$ treated with taping reported no adverse events among participants 29,36 . One study $(n=33)$ treated with taping application has reported that two participants have experienced skin allergic reactions and one person has experience dizziness as adverse reactions ${ }^{30}$.

\section{Evidence summary}

Kinesiotaping is effective in immediate pain relief with low level of evidence. Studies with moderate level of evidence suggests that kinesiotaping is effective in improvement of anxiety associated with PD. Studies with moderate level of evidence suggests that kinesio taping is at least effective as other therapies such as isometric exercises, connective tissue mobilization and medication.

\section{Discussion}


This current systematic review and meta-analysis aimed to investigate whether taping is an effective and safe treatment for PD in improving pain, anxiety and quality of life. The summarized findings of the review indicate that a weak to high level of evidence exists to support therapeutic taping in improving pain intensity, anxiety and quality of life. Further, with moderate level of evidence, our meta-analysis confirmed that taping is an effective therapeutic application in improving pain of PD. Lastly, we found adverse effects in one study, where two patients reported allergic skin reactions and one patient reported dizziness with taping.

A previous systematic review which assessed the efficacy of physiotherapy treatment for PD indicated that kinesiotaping is an effective option in improving pain, anxiety and several menstrual complaints ${ }^{37}$, similar to this review. However, López-Liria, R. et al only included one out of the nine eligible studies in this review. There are no other studies that the authors are aware of that explore the safety measures related to therapeutic taping application for PD.

According to the meta- analysis, therapeutic taping has a positive finding in improving pain intensity of females with PD. Abnormal increases of prostaglandin and vasopressin have been identified as the possible cause of PD ${ }^{38}$. This abnormal increase of the uterine hormones is known to shrink the uterus and thereby reduce blood and oxygen supply which may cause pain ${ }^{38}$. ETT applied on skin may induce underlying muscle contractions and relaxations which would improve uterine blood flow ${ }^{39}$. It is hypothesized that the pain inhibition attributed to tension generated from ETT stimulates afferent nerve fibers and facilitates pain inhibitory mechanisms ${ }^{40}$. Most included studies used kinesiotaping as the therapeutic taping application in this review. The potential pain reduction mechanism of KT application may include producing sensory tactile impulses on the skin that are able to block or reduce the arrival of pain sensations to the brain ${ }^{41}$. Also, KT application may increase blood flow by microscopically lifting the skin from the facia and activating the skin - organ reflex ${ }^{42-44}$. Though we found the adverse effects pf skin allergies and dizziness associated with therapeutic taping, considerably those adverse effects are minor and are no worse that adverse effects reported with the use of medication such as NSAIDs ${ }^{45}$.

This is the first systematic review and meta-analysis to assess the effects of therapeutic taping for PD. There are several strengths of this review which include the comprehensive search strategy and the eligibility criteria we used to retrieve studies which used all types of therapeutic taping applications. All included studies used validated outcome measures of pain, anxiety and quality of life such as VAS, NRS, STAI and Q-LES-Q-SF. This review provides a rigorous view of the current evidence related to the therapeutic taping usage for PD. Additionally, this review provides directions to conduct future RCTs with higher quality to evaluate the safety and effectiveness of therapeutic taping application for PD. Studies which used sham or no intervention control groups provide useful information on the natural regression of clinical symptoms and placebo effect due to treatment expectations.

Some limitations have to be acknowledged. Studies were only included if they were published in English, potentially limiting the inclusion of all relevant research on this topic. The quality of the included studies was fair to good. Only two studies concealed participant allocation and only one study blinded the assessors. None of the studies blinded their subjects or therapists. These methodological flaws may pose a significant risk of bias. There were limited studies that could be pooled into a meta-analysis due to heterogeneity observed in outcomes and comparison groups. Lack of consistent diagnostic criteria between RCTs may also have a negative impact on the review. Most RCTS included a short term follow up, hence the systematic review is only adequate to determine short term efficacy of therapeutic taping. Only three out of nine studies have investigated the adverse reactions related to therapeutic taping, other studies did not describe the safety aspects of therapeutic taping application.

Future RCTs should consider improving the quality of the methods in terms of allocation concealments and subject blinding to avoid possible biases. Further studies with appropriate study designs are necessary to determine the efficacy and safety of therapeutic taping as an adjunct to other interventions. RCTs with longer follow-up duration should be conducted to determine the long-term effects of therapeutic taping on PD.

This systematic review indicates that the ETT provides an efficient and safe alternative to pharmacological intervention for PD. This conclusion should be verified through high quality RCTs with larger sample sizes. Future RCTs should be designed with better methodological quality and longer follow-up to establish a firm conclusion on the usage of therapeutic for PD.

\section{Declarations}

\section{Author contributions}

Study concept and design: $A B$

Data search: KB

Design of data analysis plan: $A B$, IK, and IW

Study screening, data extraction and quality assessment: $A B$, and IK

Analysis and interpretation: $A B$, IK, and IW

Drafting of manuscript and approval of the final manuscript: $A B$, IK, IW, and KB

\section{Funding}

This study has no funding

\section{Competing interests}


The author(s) declared no competing interests.

\section{References}

1. Lobo, R.A., Gershenson, D.M., Lentz, G.M. \& Valea, F.A. Comprehensive Gynecology. (Elsevier, 2016)

2. Al-Matouq, S. et al. Dysmenorrhea among high-school students and its associated factors in Kuwait. BMC Pediatr. 19, (2019).

3. Patel, V.,Tanksale, V., Sahasrabhojanee, M., Gupte, S., \& Nevrekar, P. The burden and determinants of dysmenorrhoea: a population-based survey of 2262 women in Goa, India. BJOG. 113(4), 453-463 (2006)

4. Bernardi, M., Lazzeri, L., Perelli, F., Reis, F. \& Petraglia, F. Dysmenorrhea and related disorders. F1000Research. 6, 1645 (2017).

5. Weissman, A.M., Hartz, A.J., Hansen, M.D., \& Johnson, S.R., The natural history of primary dysmenorrhoea: a longitudinal study. BJOG. 111(4), 345-352 (2004)

6. Latthe, P., Latthe, M., Say, L., Gülmezoglu, M., \& Khan, K.S. WHO systematic review of prevalence of chronic pelvic pain: a neglected reproductive health morbidity. BMC Public Health. 6, 177 (2006)

7. Proctor, M. \& Farquhar, C. Diagnosis and management of dysmenorrhoea.BMJ.332(7550),1134-1138(2006)

8. Unsal, A., Ayranci, U., Tozun, M., Arslan, G. \& Calik, E. Prevalence of dysmenorrhea and its effect on quality of life among a group of female university students.Ups. J. Med. Sci.115 (2),138-145(2010)

9. Harada, T. Dysmenorrhea and endometriosis in young women. Yonago. Acta. Med.56 (4),81-84(2013)

10. lacovides, S., Avidon, I. \& Baker, F. C. What we know about primary dysmenorrhea today: a critical review.Hum. Reprod. Update.21 (6),762-78(2015)

11. Ju, H., Jones, M. \& Mishra, G. The Prevalence and Risk Factors of Dysmenorrhea.Epidemiol. Rev.36,104-113(2013)

12. Latthe, P., Mignini, L., Gray, R., Hills, R. \& Khan, K. Factors predisposing women to chronic pelvic pain: systematic review.BMJ. 332(7544),749-755(2006)

13. Subasinghe, A. K. et al. Prevalence and severity of dysmenorrhoea, and management options reported by young Australian women.Aust. Fam. Physician.45 (11),829-834(2016)

14. Samba Conney, C., Kretchy, A., Asiedu-Danso, I. \& Allotey-Babington, G. M. \& Complementary and alternative medicine use for primary dysmenorrhea among senior high school students in the western region of Ghana. Obstet. Gynecol. Int. 2019, 1-8 (2019).

15. Ortega, A., Cardona, J. \& Hidalgo, M. Gynecological pathology in primary care. FMC. 14(Protocol-3), 7-37(2007)

16. Goldzieher, J. W., Moses, L. E., Averkin, E., Scheel, C. \& Taber, B. Z. A placebo-controlled double-blind crossover investigation of the side effects attributed to oral contraceptives. Fertil. Steril.22,609-623(1971)

17. Rahnama, P., Montazeri, A., Huseini, H. F., Kianbakht, S. \& Naseri, M. Effect of Zingiber officinale R. rhizomes (ginger) on pain relief in primary dysmenorrhea: a placebo randomized trial.BMC Complement. Altern. Med.12,92(2012)

18. Barnard, N. D., Scialli, A. R., Hurlock, D. \& Bertron, P. Diet and sex-hormone binding globulin, dysmenorrhea, and premenstrual symptoms.Obstet. Gynecol.95,245-250(2000)

19. Sharghi, M. et al. An update and systematic review on the treatment of primary dysmenorrhea.JBRA Assist. Reprod. 23(1),51-57(2019)

20. Kannan, P. \& Claydon, L. S. Some physiotherapy treatments may relieve menstrual pain in women with primary dysmenorrhea: a systematic review.J. Physiother.60(1),13-21(2014)

21. Gerzson, L., Padilha, J., Braz, M. \& Gasparetto, A. Physiotherapy in primary dysmenorrhea: literature review.Revista. Dor.15,290-295(2014).

22. Ru, E. Clinical Notes 11 Spiral Taping. Academia.edu(2021). at https://www.academia.edu/36514701/Clinical_Notes_11_Spiral_Taping

23. Danaka, N. Spiral balance taping therapy. Gangju. Pyungwha ME CO(1997)

24. Gürşen, C., İnanoğlu, D., Kaya, S., Akbayrak, T. \& Baltacı, G. Effects of exercise and Kinesio taping on abdominal recovery in women with cesarean section: a pilot randomized controlled trial.Arch. Gynecol. Obstet.293,557-565(2015).

25. Kase, K., Wallis, J. \& Kase, T. Clinical therapeutic applications of the Kinesio taping method (Kinesio Taping Association International, 2003).

26. Maher, C., Sherrington, C., Herbert, R., Moseley, A. \& Elkins, M. Reliability of the PEDro scale for rating quality of randomized controlled trials.Phys. Ther.83,713-721(2003).

27. Cupler, Z., Alrwaily, M., Polakowski, E., Mathers, K. \& Schneider, M. Taping for conditions of the musculoskeletal system: an evidence map review.Chiropr. Man.Ther.28, (2020).

28. Boguszewski, D. et al. Effectiveness of kinesiotaping for the treatment of menstrual pain.Physiother. Q.28,20-24(2020).

29. Toprak Celenay, S., Kavalci, B., Karakus, A. \& Alkan, A. Effects of kinesio tape application on pain, anxiety, and menstrual complaints in women with primary dysmenorrhea: A randomized sham-controlled trial.Complement. Ther. Clin. Pract.39,101148(2020).

30. Yum, K., Kang, S. \& Han, H. The effect of balance taping for prevention of menstrual pain in female middle school students.J. Phys. Ther. Sci.29,813818(2017).

31. Lim, C., Park, Y. \& Bae, Y. The effect of the kinesio taping and spiral taping on menstrual pain and premenstrual syndrome.J. Phys. Ther. Sci.25,761764(2013)

32. Tomás-Rodríguez, M. et al. Effectiveness of medical taping concept in primary dysmenorrhoea: a two-armed randomized trial.Sci. Rep.5, (2015).

33. Pazare, S., Sawant, L. \& Ingale, S. The effects of kinesio taping and isometric exercises on pain in primary dysmenorrhea-a comparative study.Indian. J. Physiother. Occup. Ther.13,117(2019). 
34. Kaur, A., Ray, G. \& Mitra, M. Comparing the effectiveness of connective tissue mobilisation and kinesio-taping on females with primary dysmenorrhea.Indian. J. Physiother. Occup. Ther.11,70(2017).

35. Abedel, A., Mohamed, H. \& Mohamed Hafez, A. Effect of practicing pelvicrocking exercises on primary dysmenorrhea among adolescent girls: a randomized controlled trial. Egypt. J. Health Care.8,241-255(2017).

36. Doğan, H., Eroğlu, S. \& Akbayrak, T. The effect of kinesio taping and lifestyle changes on pain, body awareness and quality of life in primary dysmenorrhea.Complement. Ther. Clin. Pract.39,101120(2020).

37. López-Liria, R. et al. Efficacy of Physiotherapy Treatment in Primary Dysmenorrhea: A Systematic Review and Meta-Analysis.Int. J. Environ.Res. Public Health.18,7832(2021).

38. Stewart, K., Deb, S. \& Dysmenorrhoea Obstet. Gynaecol. Reprod. Med.24,296-302(2014).

39. Koo, J., University, P. \& Um, K. Effects of Kinematic Taping Therapy on Dysmenorrhea. J.Int. Acad. Phys. Ther. Res. 9,1442-1446(2018).

40. Artioli, D. \& Bertolini, G. Kinesio taping: application and results on pain: systematic review.Fisioter. Pesqui.21,94-99(2014).

41. Melzack, R. \& Wall, P. D. Pain mechanisms: a new theory.Science.150, 971-979(1965)

42. Tantawy, S. \& Kamel, D. Effect of kinesio taping on pain post laporoscopic abdominal surgery: randomized controlled trial.Int. J. Ther. Rehabil. Res.4,250(2015).

43. Krajczy, M., Luniewski, J., Bogacz, K. \& Szczegielniak, J. Evaluation of applying Kinesio taping in children with urinary incontinence. J. Pediatr. Urol. 14, 550.e1-550.e6(2018).

44. Krajczy, M., Bogacz, K., Luniewski, J. \& Szczegielniak, J. The influence of kinesio taping on the effects of physiotherapy in patients after laparoscopic cholecystectomy,Sci. World J.2012 (2012)

45. Marjoribanks, J., Ayeleke, R., Farquhar, C. \& Proctor, M. Nonsteroidal anti-inflammatory drugs for dysmenorrhoea. Cochrane Database Syst. Rev, https://doi.org/10.1002/14651858.cd001751.pub3 (2015).

\section{Figures}

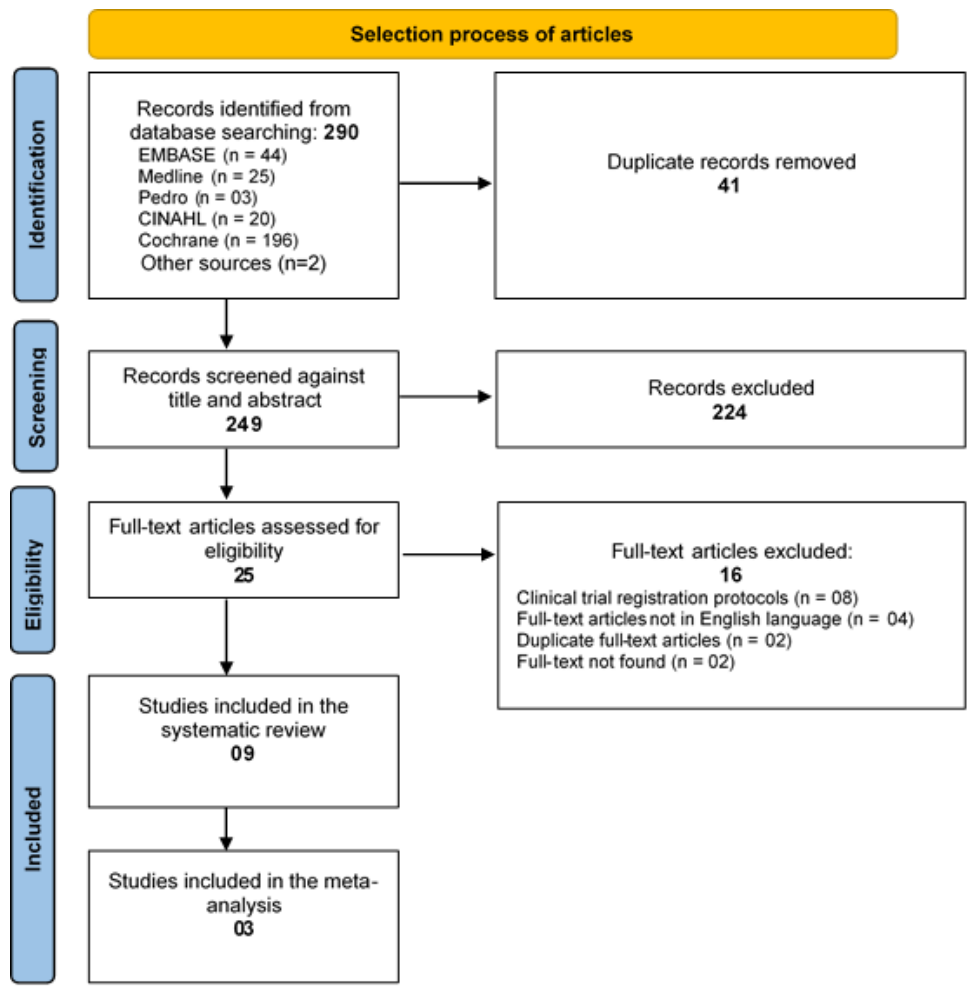

Figure 1

PRISMA flowchart of the study 


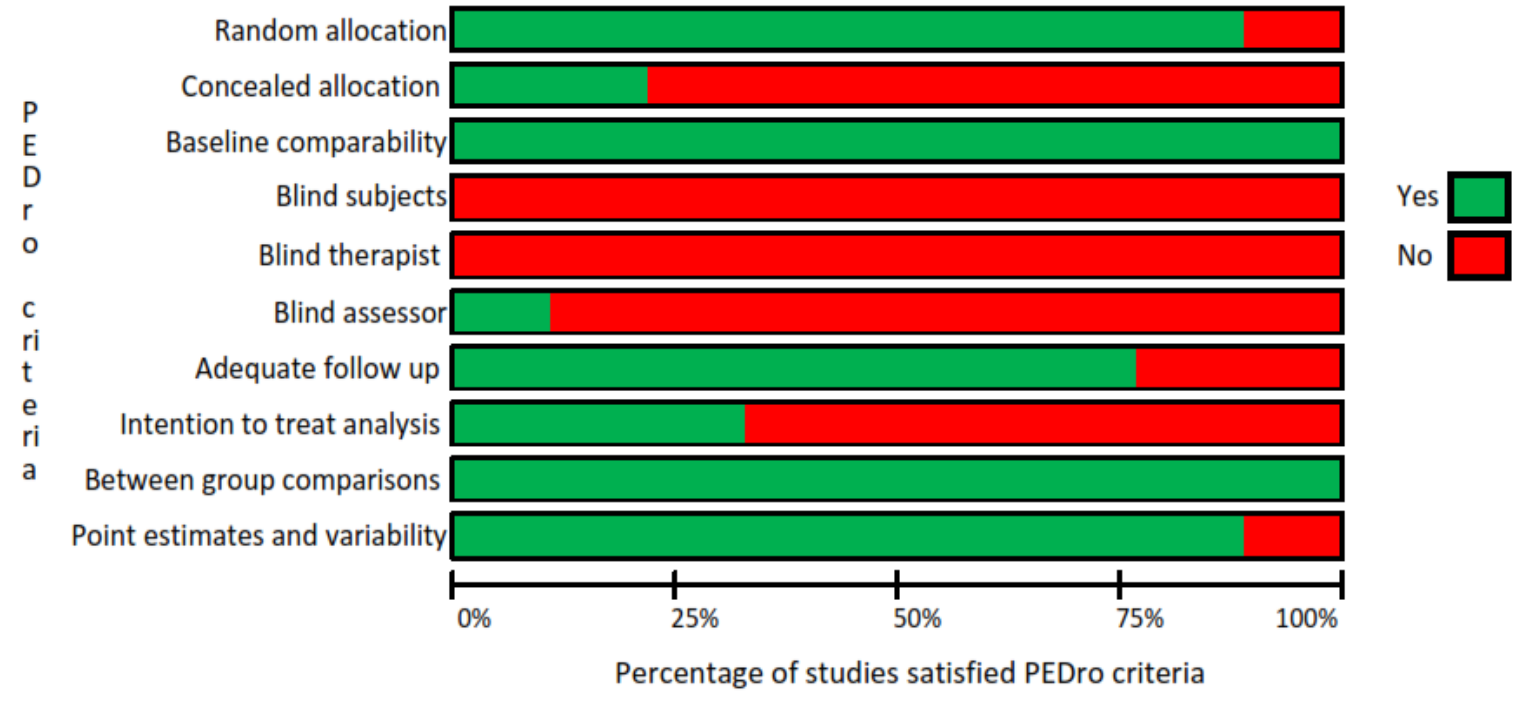

Figure 2

Quality assessment (Pedro Scale)

\begin{tabular}{|c|c|c|c|c|c|c|c|c|c|c|}
\hline \multirow[b]{2}{*}{ Study or Subgroup } & \multicolumn{3}{|c|}{ Taping } & \multicolumn{3}{|c|}{ Control } & \multicolumn{2}{|r|}{ Mean Difference } & \multirow{2}{*}{\multicolumn{2}{|c|}{$\begin{array}{c}\text { Mean Difference } \\
\text { IV, Random, } 95 \% \mathrm{Cl}\end{array}$}} \\
\hline & Mean & SD & Total & Mean & SD & Total & Weight & IV, Random, $95 \% \mathrm{CI}$ & & \\
\hline Celenay et al, 2020 & 3.25 & 1.72 & 15 & 6.44 & 1.53 & 15 & $32.8 \%$ & $-3.19[-4.35,-2.03]$ & - & \\
\hline Um et al, 2013 & 3.3 & 1.4 & 11 & 8.5 & 1.4 & 13 & 33.0\% & $-5.20[-6.32,-4.08]$ & - & \\
\hline Tomás-Rodríguez et al, 2015 & -0.34 & 2.5 & 75 & 0.71 & 1.82 & 54 & $34.2 \%$ & $-1.05[-1.80,-0.30]$ & 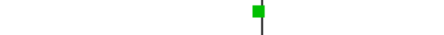 & \\
\hline \multirow{2}{*}{\multicolumn{10}{|c|}{ 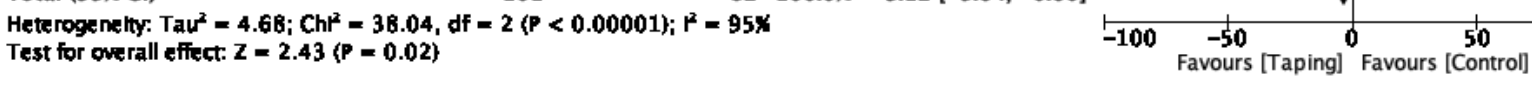 }} & \\
\hline & & & & & & & & & & 100 \\
\hline
\end{tabular}

Figure 3

$\mathrm{MD}(95 \% \mathrm{Cl})$ of the effect of taping on pain intensity of 183 females with PD as pooled from three studies. Cl, confidence interval; SD, standard deviation; MD, mean difference 